\title{
The Agar Production, Pigment and Nutrient Content in Gracilaria sp. Grown in Two Habitats with Varying Salinity and Nutrient Levels
}

\author{
Ervia Yudiati ${ }^{1,2, *}$, Annisa Afifah Nugroho $^{1}$, Sri Sedjati ${ }^{1}$, Zaenal Arifin ${ }^{3}$, Ali Ridlo ${ }^{1}$ \\ ${ }^{1}$ Department of Marine Science, Faculty of Fisheries and Marine Science, Diponegoro University, Jl. Prof. Soedarto, SH Tembalang, \\ Semarang, 50275; ${ }^{2}$ Laboratory of Marine Micro/Macroalgae Technology, Department of Marine Science, Faculty of Fisheries and Marine \\ Science, Diponegoro University, Jl. Prof. Soedarto, SH Tembalang, Semarang, Indonesia $50275 ;{ }^{3}$ Brackishwater Aquaculture Development \\ Centre, Jl.Cik Lanang, Jepara, Central Java, Indonesia
}

Received: March 22, 2020; Revised: Oct 10, 2020; Accepted: Nov 12, 2020

\begin{abstract}
Gracilaria sp. is rich in agar, pigment, carbohydrate and mineral contents. This study aims to determine the content of agar, chlorophyll a, carotenoids and nutrient content (protein, carbohydrate, total lipid, ash, water) in Gracilaria sp. grow in different habitats with high and low salinity. Samples were brought from high salinity $(44 \pm 0.33)$ ppt from the reservoir habitat and low salinity (26.98+0.15 ppt) from biofilter's shrimp waste pond habitat. Salinity and water quality parameteres were observed in three different subsites. Agar was extracted by alkali methods. Agar spectra were compared to standard agarose and characterized by FT-IR analysis. Results showed that agar content ( $25.79 \pm 0.28 \%)$, chlorophyll a $(25.79 \pm 0.28$ $\mathrm{mg} / \mathrm{g})$, carotenoid $(5.90 \pm 0.07 \mu \mathrm{mol} / \mathrm{g})$ on low salinity was significantly higher $(\mathrm{P}<0.05)$ than high salinity. In high salinity, the agar $(6.6+0.34 \%)$, chlorophyl a $(3.62 \pm 0.15$, carotenoids $(0.71 \pm 0.1 \mu \mathrm{mol} / \mathrm{g})$ contents was lower. The protein level of low salinity $(14.4 \pm 0.70 \%)$ was also significantly higher compared to high salinity $(8.15 \pm 0.25 \%)$, respectively. The total lipid, carbohydrate, water, and ash content were similar. FT-IR analysis spectra show the presence of 3,6-anhydro-L-galactose. These can be useful data concerning optimum salinity in Gracilaria sp. culture.
\end{abstract}

Keywords: Salinity, Gracilaria sp., Agar, Pigment, Nutrient content

\section{Introduction}

Naturally, Gracilaria sp. is a euryhaline macroalga (Kumar et al., 2010), has grown all over the coast with high economic value due to its nutrient content (Du et al., 2016; Hernandez, 2017). Gracilaria/Gracilariopsis have been mostly cultivated in Asia, especially Indonesia and China. The production is about $98 \%$ of global production (FAO, 2016; Kim et al., 2017). Asian people consume seaweed daily (Cikos et al., 2018). Seaweed empirically improves health and able to reduce the chronic disease incidence such as cancer, cardiovascular and heart diseases (Rioux et al., 2017; Xu et al., 2017). Gracilaria sp. serves as an excellent source of polysaccharide, i.e. agar (Xu et al., 2017) also rich in pigmented antioxidants such as chlorophyll and carotenoids (Stengel et al., 2015; Asih et al., 2019). Polysaccharides from seaweed are frequently related to pharmacological activities (Hamed et al., 2015) such as anticoagulant, antioxidant (Yudiati et al., 2018a; 2018b), antitumor, and immunomodulatory of shrimp (Litopenaeus vannamei) (Yudiati et al., 2016, 2019) as well as Zebrafish (Yudiati et al., 2020)

Common salinity at sea in marine waters is around 35 ppt. Precipitation or freshwater influxes, as in reservoir and mangrove areas, may lead to salinity variation from 10 to 70 (Graham \& Wilcox, 2000; Kumar et al., 2010). Some former researchers have reported the response of estuarine macroalgae to the abiotic factors such as salinity light, $\mathrm{pH}$, temperature, nutrient load (Kumar et al., 2010; Choi et al., 2010) associated to agar yield (Israel et al., 1999) and photosynthetic performance (Phooprong et al., 2007). Later studies have also discussed the possible effects of environmental stresses on seaweed extracts according to its kinetic parameters (Deyab, 2016).

Salinity has been displayed to the reason of osmotic (Kumar et al., 2010) as well as turgor pressure regulation (Pereiera et al., 2017). Salinity will improve the upregulation and accumulation of the essential enzymes (Odat, 2018). The seaweed tolerance to high salinity is supported by the internal and external osmotic capacities and on elasticity of the cell wall (Wu et al., 2018). When the cell is located in hypertonic solution, water will flow quickly out of the cell, and turgor pressure will be decreased affecting plasmolysis, which is commonly permanent. If the cell is located in hypotonic solution, water will go into the cell, causing an enlarge of cell volume. Salinity in plants also stimulates the ROS generation which produces cellular oxidative damage when overproduced in large amounts (Luis et al., 2018). These mechanisms play a role in combating the accumulation of reactive oxygen species (ROS) by a diverse set of enzymes such the superoxide dismutase (SOD), which dismutase the $\mathrm{O}_{2}$-radicals to $\mathrm{H}_{2} \mathrm{O}_{2}$ (Luis et

\footnotetext{
* Corresponding author e-mail: eyudiati@gmail.com.
} 
al., 2018). Gracilaria sp. is abundant in chlorophyll a and carotenoids. The pigment important role is to neutralize the free radicals (Sedjati et al., 2020). In some periods of time, these mechanisms influence the agar, pigment as well as protein and mineral content caused by salinity stress. The objective of this study is to determine the agar, pigment (chlorophyll a and carotenoids) and nutrient content (water, protein, total lipid, ash, carbohydrate) from low (reservoir) and high (biofilter habitats) salinity of Gracilaria sp.

\section{Materials and Methods}

\subsection{Water Quality Parameters}

Measurements of water quality parameters such as salinity (Atago Refractometer), $\mathrm{pH}$ ( $\mathrm{pH}$ meter RoHS), dissolved oxygen and water temperature (Water Quality Checker "Amstast") nitrate and phosphate content was administered. Assessment on nitrate content (SNI-062480-1991) was applied spectrophotometrically (Shimadzu 1900) while the phosphate content was done by Badan Standarisasi Nasional methods (SNI-06-2412-1991).

\subsection{Site Location and Sample Preparation}

Sample was collected from low salinity/LS (reservoir) and shrimp (Litopenaeus vannamei) pond waste (biofilter), which represents high salinity/HS of Center of Brackishwater and Aquaculture Development Center, Jepara, Central Java, Indonesia (Figure 1). Cordinates of sampling sites in HS was S 06 ${ }^{\circ} 35^{\prime} 12.74 "$ E 110 39'10.32" while in LS was S $06^{\circ} 35^{\prime} 05.64 "$ E $110^{\circ} 38^{\prime} 49.03^{\prime \prime}$. The salinity of the reservoir from this study tends to be mildlow salinity. In contrast, biofilter shallow waters illustrate the different condition. The water supply of biofilter came from shrimp (L. vannamei) pond waste from uneaten feed and shrimp's fecal. Due to the static and unchanged water supply, biofilter media was relatively high in salinity.

The water and Gracilaria sp. sample was taken at three different subsites from two different habitats at $800 \mathrm{~cm}$ in depth. Seaweed was taken randomly. Soon as arrived at the laboratory, samples were rinsed with tap water to clean up from debris and salt. This was followed by dried up samples indoor with room temperature. Dried Gracilaria sp. was cut off to $0.5 \mathrm{~cm}$ and then stored in a clean and dry pack and sealed with aluminium foil

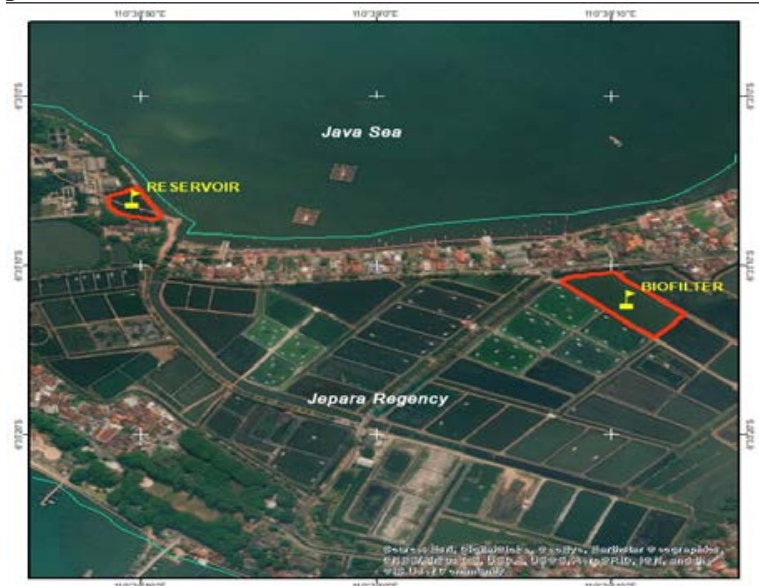

Figure 1. Site location of Gracilaria sp. samples (reservoir and shrimp pond biofilter).

\subsection{Pigment Extraction}

Pigment extraction was administered by single extraction. Ethyl acetate was used (1:10) to extract the dried seaweed for $24 \mathrm{hr}$ maceration at room temperature (Hidayati et al., 2019). Whatman no. 41 was used to sieve the extract. The extract was then concentrated with a rotary evaporator (Bucchi) and stored in a refrigerator and ready to use. Percentage of yield was calculated using the formula:

Yield (\%) = weight of extract (g)/weight of seaweed x 100\%

\subsection{Determination on Chlorophyll a and Caroteniods Contents}

Chlorophyll a and carotenoids (Dere, 1993; Harborne, 1984) content were done spectrophotometrically (Shimadzu 1800). Five g of extract was diluted with acetone p.a. (1:1) The absorbance of samples was recorded at $645 \mathrm{~nm}, 663 \mathrm{~nm}$ dan $470 \mathrm{~nm}$ wavelength. The chlorophyll a and carotenoids content was determined based on this formulation

Chlorophyll a $\mu \mathrm{g} / \mathrm{g}$ sample $(\mathrm{Ca})=12.21 \times \mathrm{A} 663-2.81 \times \mathrm{A} 646$

Carotenoids $\mu \mathrm{mol} / \mathrm{g}$ sample $(\mathrm{Cx}+\mathrm{c})=$

\section{$A 470+0.114 x A 663-0.638 x A 646) x V x 1000$}

\section{$112.5 \times 0.1 \times 10$}

\subsection{Agar extraction}

Agar extraction methods were basically done by Jayasinghe et al., (2016) with some modifications. Fifty grams of dried seaweed was extracted for $1.5 \mathrm{hr}$ in hot water $\left(85^{\circ} \mathrm{C}\right)$ added with $750 \mathrm{~mL} \mathrm{NaOH} 5 \%$. The extract was then rinsed with continuous tap water for discoloration. This was followed by aquadest $750 \mathrm{~mL}$ and homogenized. Acetic acid $\left(\mathrm{CH}_{3} \mathrm{COOH}\right)$ was then added, stirred and boiled at $\pm 90-95^{\circ} \mathrm{C}$ for two hrs. The agar was then sieved, dropped with $\mathrm{KCl} 6 \mathrm{~g}$, homogenized and poured into the container. Finally, 18 hrs later, the gel was performed and yield (\%) was counted.

\subsection{Nutrient Content}

The proximate analysis was referred to as the Association of Official Analytical Chemists (AOAC, 2005) and conducted to $5 \mathrm{~g}$ samples.

\subsubsection{Water content}

Sample was put into the oven $\left(105^{\circ} \mathrm{C}\right)$ for three hrs. Dried samples were then placed into dessicator until the weight was constant.

Water content $(\%)=\frac{a-b}{c} \times 100 \%$

$\mathrm{a}=$ cup + dried sample

$\mathrm{b}=$ cup without sample

$\mathrm{c}=$ initial samole weight

\subsubsection{Protein Analysis}

Protein analysis was done by Kjeldahl methods, by located samples into Kjeldahl vial and destructed using 20 $\mathrm{mL}$ of hot sulfuric acid. The process was continued until samples were colorless and clear. This was then diluted and distilled with $10 \mathrm{~mL}$ of $\mathrm{NaOH} 10 \%$. The distillate was then put into $25 \mathrm{~mL}$ of $3 \% \mathrm{H}_{3} \mathrm{BO}_{3}$ and titered with $\mathrm{HCl}$ standard using methyl red as an indicator. The volume of titrants was used to calculate the percentage of total 
nitrogen. The protein level was counted by multiplied the total nitrogen and correction factor.

Total nitrogen $\%=\mathrm{mL} \mathrm{HCl} \times \mathrm{NHCl} /$ sample weight $\times 14008 \times \mathrm{f}$

Total protein $\%=$ total nitrogen $\times 6.25$

denoted : $\mathrm{f}=$ correction factor (6.25).

\subsubsection{Total Lipid Content}

Total lipid analysis was done by soxhlet methods. Dried samples were wrapped with cotton wool. Sample was then placed into soxhlet extractor, using diethyl ether as solvent. Reflux was conducted by the samples until done. Vial was then put into the oven $\left(105^{\circ} \mathrm{C}\right)$ and weight. The percentage of total lipid was determined by this formula:

Total lipid (\%)= Lipid weight/Sample weight $\mathrm{x} 100 \%$

\subsubsection{Ash Content}

Sample was weighed and burned at the top of bunsen until smoke produced and put in the muffle furnace at 500 - $600^{\circ} \mathrm{C}$ until turned to ash formation. Cup was cooled down and weighed. The ash content was counted using formula:

Ash content $(\%)=$ ash weight $/$ sample weight $x 100 \%$

\subsubsection{Total Carbohydrate}

Total carbohydrate was counted simply by this equation:

Total carbohydrat $(\%)=100 \%-(\%$ ash $+\%$ water $+\%$ protein + $\%$ total lipid).

\subsubsection{Characterization of Agar}

Agar characterization was determined by Fourier Transform Infrared (FT-IR) spectroscopy (Thermo Nicolet 380 FTIR, Germany). Samples were mixed with $\mathrm{KBr}$ pellets $(10 \% \mathrm{w} / \mathrm{w})$. Similar to alginate, the pellet was recorded at $4000-500 \mathrm{~cm}^{-1}$ (Yudiati and Isnansetyo, 2017).

\section{Statistical Data Analysis}

All data surveys were analyzed non parametrically (Mann Whitney test) using SPSS version 20.0 computer software. The laboratory data were analyzed using One Way ANOVA (Analysis of variance) using the same software, with a $95 \%$ level of significance.

\section{Results}

\subsection{Water Quality Parameters}

Salinity, nitrate and phosphate contents and others water quality parameter LS and HS with three subsites are shown in Table 1 . There was a differences in salinity, nitrate and phosphate contents, while other parameters were similar.
Tab1e 1. Water quality parameters of Gracilaria sp. grown in low salinity (reservoir) and high salinity (pond waste biofilter)

\begin{tabular}{lll}
\hline Parameter & LS & HS \\
\hline Temperature $\left({ }^{\circ} \mathrm{C}\right)$ & $29.74 \pm 0.15^{\mathrm{a}}$ & $29.70 \pm 0.03^{\mathrm{a}}$ \\
Salinity (ppt) & $26.89 \pm 3.15^{\mathrm{a}}$ & $44.00 \pm 0.33^{\mathrm{b}}$ \\
$\mathrm{pH}$ & $8.0 \pm 0^{\mathrm{a}}$ & $8.3 \pm 0^{\mathrm{a}}$ \\
Dissolve Oxygen (ppm) & $3.55 \pm 0,72^{\mathrm{a}}$ & $3.45 \pm 0,05^{\mathrm{a}}$ \\
Nitrate (mg/L) & $0.43 \pm 0.56^{\mathrm{b}}$ & $1.77 \pm 1.44^{\mathrm{a}}$ \\
Phosphate (mg/L) & $0.78 \pm 0.26^{\mathrm{b}}$ & $0.29 \pm 0.19^{\mathrm{a}}$ \\
\hline
\end{tabular}

4.2. Yield of pigment extraction, chlorophyll $a$ and carotenoids content

Yield, chlorophyll a and carotenoids content in reservoir and shrimp pond bioflilter is shown in Figure 1. Yield were similar, chlorophyll a and carotenoids of Gracillaria sp. sample in reservoir was higher.

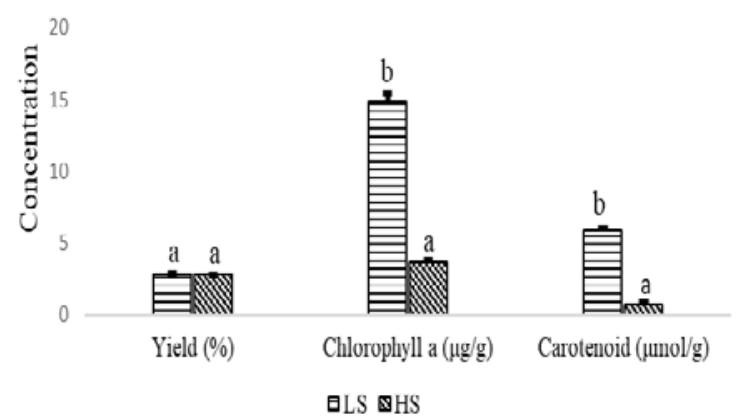

Figure 2. Yield, Chlorophyll and Carotenoids Content of Gracilaria sp. grown in high and low salinity. Different superscript indicates a significantly difference $(\mathrm{p}<0.05)$.

\subsection{Agar Percentage and Characterization}

Percentantion of agar in Gracillaria sp. samples from LS and HS is shown at Table 2. Agar characterization of sample and standard agarose (Merck, USA) is depicted in Figure 3a, b and Table 3. Concentration of agar sample from LS habitat was significantly different compared to HS $(p<0.05)$. On the other hand, pairwise comparison spectra of agar either from low or high salinity were fit to the standard.

Table 2. Percentage agar yield of Gracilaria sp. samples from low salinity (reservoir) and high salinity (biofilter)

\begin{tabular}{lc}
\hline Habitat & Agar $(\% \mathrm{w} / \mathrm{w})$ \\
\hline LS & $25.79 \pm 0.28$ \\
HS & $6.60 \pm 0.34$ \\
\hline
\end{tabular}




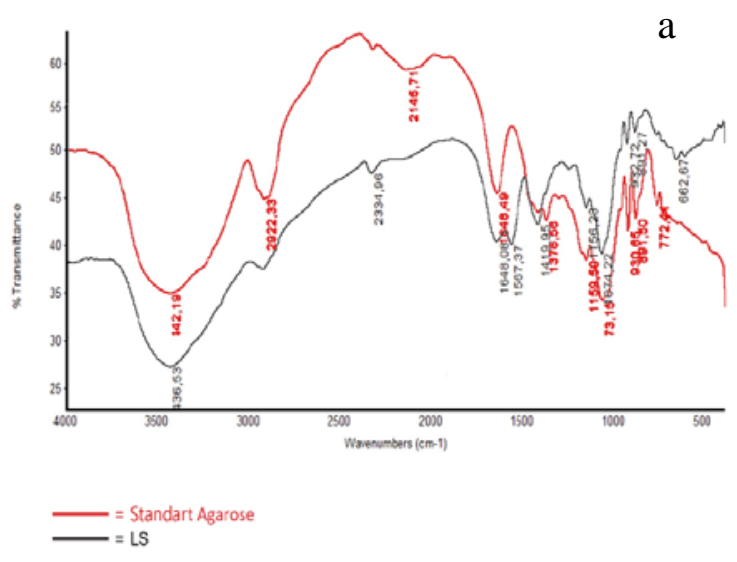

b

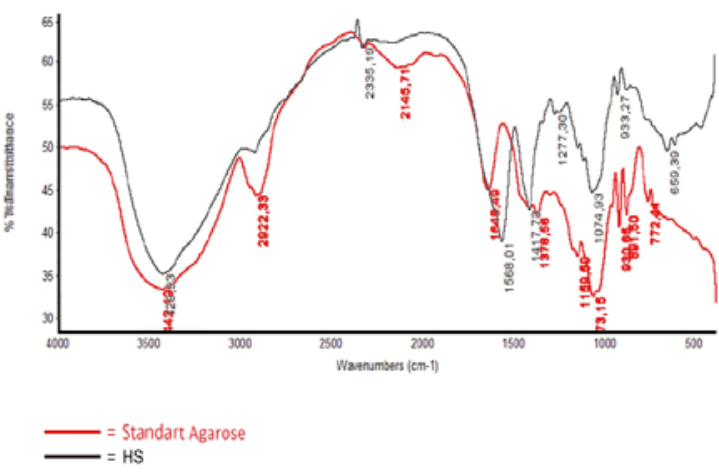

Figure 3. FT-IR spectra of agar from Gracilaria sp. from low salinity, LS (a) and high salinity, HS (b)

Table 3. The vibration signal of Standard, Low Salinity (LS) and High Salinity (HS) of Agar ( $1500-400 \mathrm{~cm}^{-1}$ )

\begin{tabular}{lll}
\hline Location & Type of Bonding & Wave Number $\left(\mathrm{cm}^{-1}\right)$ \\
\hline Standar Agarose & O-H & 930.65 bending \\
& C-H & 1378.56 deformation \\
& & 891.50 bending \\
& & 772.41 bending \\
& & \\
& C-O & 1159.50 stretching \\
& & 1073.15 stretching \\
LS & O-H & 932.72 bending \\
& C-H & 1419.95 bending \\
& & 891.27 bending \\
& & 662.67 bending \\
& C-O & 1156.23 stretching \\
& & 1074.22 stretching \\
& O-H & 933.27 bending \\
& C-H & 1417.73 bending \\
& & 1277.30 stretching \\
& C-O & 659.39 bending \\
& & 1074.93 stretching \\
\hline
\end{tabular}

\subsection{Nutrient Content}

Percentage of protein, carbohydrate, total lipid, water and ash of Gracilaria sp. samples from LS and HS is presented in Figure 4. Protein content of samples from low salinity is significantly different from the samples from high salinity $(p<0.05)$. On the other hand, other concentrations were similar.

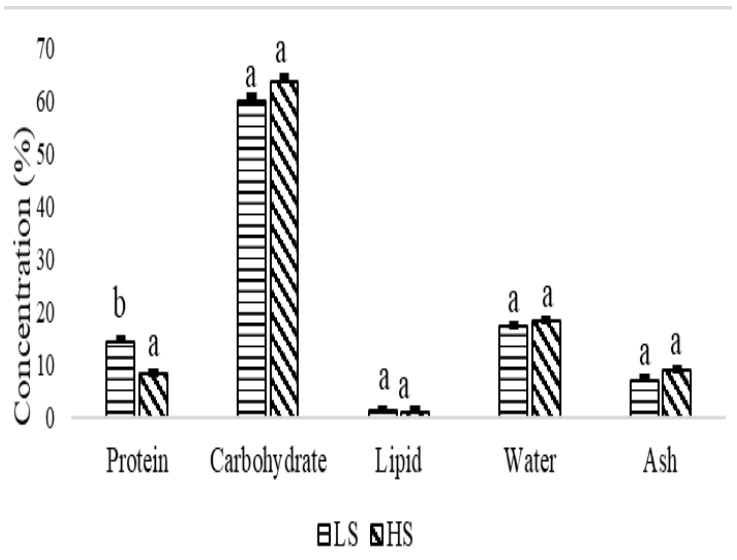

Figure 4. Protein, carbohydrate, lipid, water and ash contents of Gracilaria sp. grown in LS and HS

\section{Discussion}

\subsection{Pigment Yield, Chlorophyll $a$ and Carotenoids content of Gracilaria sp. from LS and HS}

In terms of pigment extraction yield, the extraction of Gracilaria sp. from LS and HS resulted in a similar yield $( \pm 2,8 \%)$ (Fig. 2). This value was possibly derived from other source of pigments based on water extraction from phycobiliprotein groups. Kumar et al. (2010) reported that decline concentration of chlorophyll $a$ and carotenoids was in accordance with higher allophycocyanin (APC) and phycoerythrin (PE) content in hyper-salinity (45-50 ppt). Additionally, the similar researchers stated that the increment approximately from $52 \%$ and up to $70 \%$ from initial contents. This finding was also in agreement with Pereira et al. (2017) that high salinity reducing the chlorophyll contents and depigmentation of apices.

As shown in similar figure, photosynthetic pigments i.e. chlorophyll a and carotenoids content of Gracilaria sp. samples from the LS (26.98 ppt) was significantly higher than HS (44 ppt) $(\mathrm{p}<0.05)$. Chlorophyll is a compound with free electrons structure from nitrogen atoms (Sedjati et al., 2020). Meanwhile, Martinez et al., 2010 stated that carotenoids neutralize free radicals in three ways which is electron transfer, addition of radical species and the hydrogen abstraction. This indicated that low salinity was more tolerable. So, the physiology was relatively normal. Moreover, the phenomenon of oxidative stress, osmotic and turgor pressure regulation might not appear. In addition, chlorophyll a content from the Indonesian North Java coast in this study $(14.81 \mu \mathrm{g} / \mathrm{g})$ is distinctly higher compared to the study from Thondi Coast, India (8.96 $\mu \mathrm{g} / \mathrm{g}$ ) (Rosemary et al., 2019). In addition, visually, the colour green intensity of pigment from low salinity was much brighter and darker.

In general, visually, Gracilaria sp. thallus in this present study from the LS were thicker and bigger that might be indicated the better growth. Pereira et al. (2017), Wong and Chang (2000) reported similar results. Moreover, Gracilaria tenuistipitata from Songkhla Lagoon in Thailand showed the best growth rates at the salinity of 25 psu (Bunsom and Prathep., 2012). The growth of macroalgae in the marine ecosystem is often decreased in hypersaline water. This is due to the cumulative enzyme effects such as reduction of 
turgor pressure, this then leads to restrict division of cells and at last, affected the growth (Lee and Liu, 1999).

Nitrate content at HS in this study was higher than LS (Table 1). This is probably caused by instant efflux nutrient from the shrimp pond. Pond's feed waste and shrimp faecal contribute the nitrate content. Nutrient factor highly fluctuates on photosynthesis especially nitrate and phosphate (Ismail and Osman, 2016). Research by Wu et al., (2018) reported that the nitrate and phosphorus uptake were higher at lower salinities (less than 20 psu) than higher salinity conditions (up to $20 \mathrm{psu}$ ). Study from Choi et al. (2010) exhibits that nitrate and phosphate uptake of macroalgae were greater in certain levels of salinity $(20$ and $25 \mathrm{ppt}$ ). These reports demonstrate similar suggestion to this study. Moreover, the water supply in LS from this study was more diverse, either from upside regimes from the sea as well as freshwater influxes from the river. Table 1 noted that phosphate content in LS was higher. The role of phosphate pathway is by transferring the high adenosine triphosphate (ATP) energy and other high energy compounds. This occurs in respiration and photosynthetic process (Ismail and Osman, 2016). These researchers' results were similar to our previous data, that photosynthetic pigments (chlorophyll a and carotenoids) of Gracilaria sp. in LS was higher when compared to the HS habitat (data is not shown).

\subsection{Agar Percentage and Characterization}

Data from Table 2 pointed that agar percentage of Gracilaria sp. in LS was significantly higher than HS. This is probably due to a relationship between salinity and the agar content. Research by Sasikumar et al. (1999) stated that a high salinity of $G$. verrucosa in summer (43.8\%) was found to be negatively correlated with agar yield. The best agar production of Gracilaria tenuistipitata $(24.8 \pm 3.0 \% \mathrm{DW})$ in laboratory was found at 25 psu (Bunsom and Prathep., 2012). Rocha et al. (2018) stated that, often, yield of agar of G. tikvahiae has been clearly connected with salinity and adversely with nitrogen content, similarly reported to G. gracil species (Martin et al., 2013). Nitrogen concentration in LS, in fact, is lower than HS (Table 1). Less concentration of nitrogen, synthesis of protein declines in favor of polysaccharide synthesis. However, other factors such as nutrient availability, environmental and geographic factors, seasonal variations can influence the yield, chemistry and biosynthesis of agar (Lahaye and Rochas, 1991). Moreover, Lee et al. (2017) also stated that it is not easy to investigate the effects of a single factor on the yield of agar extracted from seaweeds grown in the natural habitat.

Based on spectra of FT-IR analyses, (Figure 2) shows that two Gracilaria sp. samples are fit to the standard agarose (Merck) and positively fingerprinted at a specific agar (1500-400 $\mathrm{cm}^{-1}$ ) with galactose bond (around 1070 $\mathrm{cm}^{-1}$ ). The vibration signal is slightly different, but overall those are agar characterizations. Agarose has a basic repeating unit of 1,3-linked $\beta$-D-galactopyranose and 1,4linked 3,6-anhydro-a-L-galactopyranose. Based on figure 3 above, there is a 3,6 anhydrogalactose unit at a wave number of 928-933 $\mathrm{cm}^{-1}$ (Hii et al., 2015). Observed bands at $930 \mathrm{~cm}^{-1}$ indicates $\mathrm{O}-\mathrm{H}$ bending. The hydroxyl $(\mathrm{O}-\mathrm{H})$ unit appears at $3400 \mathrm{~cm}^{-1}$ wavenumber. Alkene $\left(\mathrm{CH}_{3}\right.$ or $\mathrm{CH}_{2}$ ) associated to metoxil appeared at $2900 \mathrm{~cm}^{-1}$.
Aldehyde group (-CHO) markedly appears at $1600 \mathrm{~cm}^{-1}$ (Pereira et al., 2009).

Based on Figure 4, it can be seen that protein content in Gracilaria sp. samples from LS was significantly higher compared to HS $(\mathrm{p}<0.05)$. Protein percentage is related to the nitrate content. In high salinity, nitrate compound has not taken up, easily (Choi et al., 2010). However, in special cases, nutrient uptake can be occasionally imbalanced during unfavorable periods of situations (Trimmer et al., 2000).

Results from Table 1 show that phosphate compound from the LS habitat was higher, and this may force the production of protein in the algal cell. Energy from photosynthesis will be used for amino acid biosynthesis that comes from the surrounding water. ATP is energy synthesized by photosynthesis, and these surely need phosphate. The reduction of protein synthesis triggered the decrease of the protein content and this was then affected the other cell components such as chlorophyll and other pigments (Ismail and Osman, 2016). This phenomenon was performed in Gracillaria sp. from HS habitat. Compared to other research, protein content in this study (14.40\%) was higher than G. changii from Sarawak, Malaysia (12.57\%) (Chan and Matanjun, 2016). Even though, this protein content was lower compared to the study on G. corticata by Rosemary et al. (2019).

Carbohydrate percentages form Gracilaria sp. samples grown in LS and HS were similar ( $>>0.05)$ (Figure 4). Carbohydrate content in this study was higher than $G$. changii (Chan and Matanjun, 2016) and G. edulis (Rosemary et al., 2019). Total lipid, water and ash content of Gracilaria sp. in both samples was not significantly different $(p>0.05)$. Generally, total lipid from all macroalgae, including Gracillaria sp. in this research, was relatively low at the range of $0.9-40 \%$ (Khairy and El Shafay, 2013). Seaweed is rich in minerals. The high ash content indicates high mineral content. In accordance to our finding, the results from Wu et al. (2018) reported that nutrient uptake, tissue nutrient contents were affected by salinity and the ideal salinity was around 20 psu. This information could be beneficial to define optimal salinity in Gracilaria sp. culture systems to get the maximal agar yield and pigment quality, protein and mineral content. This initiates better economic incomes for agarophyte farming.

\section{Conclusion}

Agar, chlorophyll a, carotenoids, protein and mineral contents of Gracilaria sp. grown from low salinity habitat (reservoir) were higher compared to high salinity habitat (biofilter shrimp ponds). Other compounds such as the total lipid, carbohydrate, water, and ash content from high and low salinity were similar. In this study, it can be concluded that salinity affected Gracilaria sp. nutrient content. Similar to the standard agar, FT-IR spectra from different salinity show the existence of 3,6-anhydro-Lgalactose. Our findings can be useful for considering the application of Gracilaria sp. culture in the future. 


\section{References}

AOAC. 2005. Oficial Methods of Analysis of the Asspciation of Official Analytical Chemist. Benyamin Franklin Station. Washingtong D.C.

Asih T, Khayuridlo M, Noor R and Muhfahroyin. 2019. Biodiversity and Potential Use of Macro Algae in Pesisir Barat Lampung. Biosaintifika, 11(1): 100-107.

Badan Standarisasi Nasional. 1991. SNI 06-2412-1991. Metode Pengambilan Contoh Uji Kualitas Air.

Badan Standarisasi Nasional. 1991. SNI 06-2480-1991. Cara Uji Nitrat Secara Spektrofotometri.

Bunsom C and Prathep A. 2012. Effects of salinity, light intensity and sediment on growth, pigments, agar production and reproduction in Gracilaria tenuistipitata from Songkhla Lagoon in Thailand. Phycological Research, 60: 169-178

Chan PT, and Matanjun P. 2016. Chemical Composition and Physicochemical Properties of Tropical Red Sea Weed, Gracilaria changii. Food Chem, (16) : 1-37. Cikos AM, Jokic S, Subaric D and Jerkovic I. 2018. Overview on the application of modern methods for the extraction of bioactive compounds from marine macroalgae. Mar Drugs, 16(10): 348-368.

Dere S, Gunes T and Sivaci R. 1998. Spectrophotometric determination of chlorophyll-a, b, and total carotenoid content of some algae species using different solvent. J of Botany, 22:13-17.

Deyab MA. 2016. Inhibition activity of Seaweed extract for mild carbon steel corrosion in saline formation water. Desalination, 385: 60-67.

Du Q, Guiqi B, Yunxiang M and Zhenghong S. 2016. The complete chloroplast genome of Gracilariopsis lemaneiformis (Rhodophyta) gives new insight into the evolution of family Gracilariaceae. J Phycol, 52 (3): 441-450

FAO. 2016. The State of World Fisheries and Aquaculture 2016 Contributing to food security and nutrition for all. Rome.

Graham LE and Wilcox LW. 2000. Algae. Prentice Hall, New York. (640pp.)

Hamed I, Özogul F, Özogul Y and Regenstein JM. 2015. Marine bioactive compounds and their health benefits: A review. Compr Rev Food Sci Food Saf, 14: 446-465

Harborne JB. 1984. Phytochemical Methods: A Guide to Modern Techniques of Plant Analysis. second ed. Chapman and Hall, London.

Hernandez A. 2017. The Effect of Salinity on the Growth of the Red Alga, Gracilaria epihippisora. Marine Science Department University of Hawai'i at Hilo.

Hidayati JR, Yudiati E, Pringgenies D, Arifin Z and Oktaviyanti DT. 2019. Sargassum sp. Extract Macerated In Different Solvents Polarity. Jurnal Kelautan Tropis, 22 (1) : 73 - 80.

Hii SL, Lim JY, Ong WT and Wong CL. 2015. Agar From Malaysian Red Seaweed as Potential Material for Synthesis of Bioplastic Film. Journal of Engineering Science and Technology Special Issue on SOMCHE, : $1-15$.

Ismail MM and Osman MEH. 2016. Seasonal fluctuation of photosynthetic pigments of most common red seaweeds species collected from Abu Qir, Alexandria, Egypt. Revista de Biología Marina y Oceanografía, 51(3): 515-525.

Israel A, Martinez-Goss M and Friedlander M. 1999. Effect of salinity and $\mathrm{pH}$ on growth and agar yield of Gracilaria tenuistipitata var. liui in laboratory and outdoor cultivation. J Appl Phycol, 11: 543-549.

Jayasinghe P, Pahalawattaarachchi S and Ranaweera KKDS. 2016. Effect of Extraction Methods on the Yield and Physiochemical Properties of Polysaccharides Extracted from
Seaweed Available in Sri Lanka. Poultry, Fisheries and Wildlife Sciences, 4(1): 1 - 6 .

Khairy HM and El-Shafay SM. 2013. Seasonal Variations In The Biochemical Composition of Some Common Seaweed Species From The Coast of Abu Qir Bay, Alexandria, Egypt. Oceanologia, 55(2):435-452.

Kim JK, Yarish C, Hwang EK, Park M and Kim Y. 2017. Seaweed aquaculture: cultivation technologies, challenges and its ecosystem services. ALGAE, 32(1): 1-13.

Kumar M, Kumari P, Gupta PV, Reddy CRK and Jha B. 2010. Biochemical responses of red alga Gracilaria corticata (Gracilariales, Rhodophyta) to salinity induced oxidative stress. $J$ Exp Mar Bio Ecol, 391: 27-34

Lahaye M. and Rochas C. 1991. Chemical-structure and physicochemical properties of agar. Hydrobiologia, 221: 137-148

Lee, TM and Liu, CH. 1999. Correlation of decreased calcium contents with proline accumulation in the marine green macroalga Ulva fasciata exposed to elevated $\mathrm{NaCl}$ contents in seawater. $J$ Exp Bot, 50:1855-1862.

Lee W-K, Lim Y-Y, Leow AT-C, Namasivayam P, Abdullah JO and Ho C-L. 2017. Factors affecting yield and gelling properties of agar. $J$ Appl Phycol, 29:1527-1540 DOI 10.1007/s10811-016-1009-y

Luis A, Corpas FJ, López-Huertas E and Palma JM. 2018. Plant Superoxide Dismutases: Function Under Abiotic Stress Conditions. Antioxidants and Antioxidant Enzymes in Higher Plants. Springer, pp1-26.

Martin LA, Rodriguez MC, Matulewicz MC, Fissore EN, Gerschenson LN and Leonardi PI. 2013. Seasonal variation in agar composition and properties from Gracilaria gracilis (Gracilariales, Rhodophyta) of the Patagonian coast of Argentina. Phycological Research, 61(3): 163-171

Odat N. 2018. Differential Gene Expression of Durum Wheat (Triticum turgidum L. var. durum) in Relation to Genotypic Variation under $\mathrm{NaCl}$ Salinity Stress. Jordan Journal of Biological Science, 11(5): 591-595

Phooprong S, Ogawa H and Hayashizaki K. 2007. Photosynthetic and respiratory

responses of Gracilaria salicornia (C. Agardh) Dawson (Gracilariales, Rhodophyta)

from Thailand and Japan. J Appl Phycol, 19: 795-801.

Pereira L, Amando AM, Critchley AT, Velde FVD and Ribeiro PJA. 2009. Identification of Selected Seaweed Polysaccharides (Phycocolloids) by Vibrational Spectroscopy (FTIR-ATR and FTRaman). Food Hydrocol, 300: (1-7).

Pereira, DT, Simioni C, Filipin EP, Bouvie F, Ramlov F, Maraschin M., Bouzon ZL and Schmidt EC. 2017. Effects of salinity on the physiology of the red macroalga, Acanthophora spicifera (Rhodophyta, Ceramiales). Acta Bot Brasilica, 31(4):555-565

Rioux LE, Beaulieu L and Turgeon SL. 2017. Seaweeds: A traditional ingredients for new gastronomic sensation. Food Hydrocoll, 68: 255-265.

Rocha CMR, Sousa AMM, Kim JJ, Magalhães JMCS, Yarish C and Gonçalves MP. 2018. Characterization of agar from Gracilaria tikvahiae cultivated for nutrient bioextraction in open water farms. Food Hydrocoll, doi: https://doi.org/10.1016/j.foodhyd.2018.10.048.

Rosemary T, Arulkumar A, Paramasivam S, Mondragon A and Miranda JM. 2019. Biochemical, Micronutrient and Physicochemical Properties of the Dried Red Seaweeds Gracilaria edulis and Gracilaria corticata. Molecules, 24 (2225) : 1-5. 
Sasikumar C, Rao VNR and Rengasamy R. 1999. The effect of environmental factors on the qualitative and quantitative characteristics of agar from the marine red alga Gracilaria verrucosa (Gracilariales, Rhodophyta). Indian J Mar Sci, 28:270273

Sedjati S, Pringgenies D and Fajri M. 2020. Determination of the Pigment Content and Antioxidant Activity of the Marine Microalga Tetraselmis suecica. Jordan Journal of Biological Sciences, 13(1): 55-58

Stengel DB and Connan S. 2015. Marine algae: a source of biomass for biotechnological applications, in: D.B. Stengel, S. Connan (Eds.), Natural Products From Marine Algae - Methods and Protocols, Humana Press, New York, NY, 2015, pp. 1-37, https://doi.org/10.1007/978-1-4939-2684-8_1.

Trimmer M, Nedwell DB, Sivyer DB and Malcolm SJ. 2000. Seasonal organic mineralisation and denitrifcation in intertidal sediments and their relationship to the abundance of Enteromorpha sp. and Ulva sp. Mar Ecol Prog Ser, 203:67-80.

Wong SL and Chang J. 2000. Salinity and light effects on growth, photosynthesis, and respiration of Grateloupia filicina (Rhodophyta). Aquaculture, 182:387-395

Wu H, Shin SK, Jang S, Yarish C and Kim JK. 2018. Growth and Nutrient Bioextraction of Gracilaria chorda, G. vermiculophylla, Ulva prolifera, and U. compressa Under Hypo- and HyperOsmotic Conditions. ALGAE, 33(4): 329-340.

Xu SY, Xuesong $\mathrm{H}$ and Kit-Leong C. 2017. Recent Advances in Marine Algae Polysaccharides: Isolation, Structure, and Activities. A review. Mar Drugs, 15 (388) : 1-16

Xu SY, Huang X and Cheong KL. 2017. Recent Advances in Marine Algae Polysaccharides: Isolation, Structure, and Activities. Mar Drugs, 15 (388): 1-16
Yudiati E and Isnansetyo A. 2017. Characterizing the Three Different Alginate Type of Sargassum siliquosum. ILMU KELAUTAN: Indonesian Journal of Marine Sciences, 22(1):7-14

Yudiati E, Isnansetyo A, Ayuningtyas, Handayani CR, Murwantoko and Triyanto. 2016. Innate immune-stimulating and immune genes up-regulating activities of three types of alginate from Sargassum siliquosum in Pacific white shrimp, Litopenaeus vannamei. Fish \& Shellfish Immunol. 54: 4653.

Yudiati E, Santosa GW, Tontowi MR, Sedjati S, Supriyantini E and Khakimah M. 2018a. Optimization of alginate alkaline extraction technology from Sargassum polycystum and its antioxidant properties. IOP Conf. Ser.: Earth Environ. Sci.139. 012052. doi :10.1088/1755-1315/139/1/012052

Yudiati E, Pringgenies D, Djunaedi A, Arifin Z and Sudaryono A. 2018b. Free radical Scavenging of Low Molecular Weight Sodium Alginate (LMWSA) from Sargassum polycystum Produced by Thermal Treatment. Aquac Ind, 19 (1): 21-27.

Yudiati E, Isnansetyo A, Murwantoko, Triyanto and Handayani CR. 2019. Alginate from Sargassum siliquosum Simultaneously Stimulates Innate Immunity, Upregulates Immune Genes, and Enhances Resistance of Pacific White Shrimp (Litopenaeus vannamei) Against White Spot Syndrome Virus (WSSV). Marine Biotechnology 21(4):503-514. https://doi.org/10.1007/s10126019-09898-7

Yudiati, E, Rustadi, Ginzel FI, Hidayati JR., Rizfa MS, Azhar N, Djarod MSR, Heriyati E, and Alghazeer R. 2020. Oral Administration of Alginate Oligosaccharide from Padina sp. Enhances Tolerance of Oxygen Exposure Stress in Zebrafish (Danio rerio). ILMU KELAUTAN: Indonesian Journal of Marine Sciences 25(1):7-14. 